\title{
Testing laboratory parameters of compost tea
}

\author{
Edit Gorliczay - Dénes Pecsmán - János Tamás \\ University of Debrecen, Faculty of Agricultural and Food Sciences and Environmental Management \\ Institute of Water and Environmental Management, Debrecen, Hungary \\ edit.gorliczay@agr.unideb.hu
}

\begin{abstract}
SUMMARY
During the industrial production of broiler chicken, a large amount of manure is produced, of which easily contained nitrogen content (without pre-treatment) is released into the atmosphere as an air pollutant. In our experiments, we aimed to prepare compost tea, also known as water extract of compost, from pre-treated poultry manure in order to create a product can be utilized as liquid nutrient supply. The poultry manure source was the Baromfi-Coop Ltd. located in Nyírjákó, Hungary, where it was treated by composting. As a result of this pre-treatment of the poultry manure, its nutrient parameters improve and nitrogen is present in a form that is better utilized for plants. Furthermore, this product is suitable for further utilization and also can be the base material for a brand-new product. For this reason the effects of compost/water ratio, incubation time, low oxygen level, and extraction time on the parameters of the resulted product were studied in the frame of developing new soil-life enhancing microbial product, so-called compost tea.

Chemical parameters of the compost used as base material strongly determined the properties of the resulted compost tea, especially the ratio of the various nitrogen forms, their concentration and the salt content. It was found that adding water at a higher rate that means $1 / 40$ and 1/50 mixing ratios results in more cost-effective production. In the experiment the compost tea were held under oxygen-poor conditions, therefore $\mathrm{pH}$ of the extractions decreased, which influenced the quality and quantity of their nutrient content.
\end{abstract}

Keywords: composting, compost tea, poultry manure

\section{INTRODUCTION}

Conventional agriculture is characterized by the use of a large amount of synthetic fertilizers and pesticides (Matson et al. 1997). However, sustainable agriculture seeks to recycle as much by-products of farms, such as straw and manure, as possible to protect environmental quality (Vandermeer 1995, Casado and Molina 2009).

The importance of agriculture increases mainly due to population growth; therefore, traditional agriculture and traditional livestock production are becoming underrepresented compared to industrial husbandry. In many cases, this may result in increasing environmental load and risk of contamination (Gaál 2011).

Concentrated livestock production is particularly important in poultry farming, but the biggest problem is the large amount of chicken manure and the real challenge is manure storage and management (Gaál 2011). Slurry and manure can pollute the environment, especially when contaminants are concentrated in the soil, air and water (Kovács 2011). Poultry manure, similarly to other manure types, can also be applied directly in arable land and can be used for nutrient supply in crop production technologies (Csaba et al. 1978). Treating poultry manure by composting is increasingly widespread in order to modify nitrogen into a form which is more available for plants. Ogunwande et al. (2008) studied the nitrogen forms in manure, and they found, that nitrogen content loss can be reduced by $71-88 \%$ thanks to the composting. The composted manure that is the final product has two benefits: (1) its nitrogen content of easily absorbable form will not be eliminated, (2) it will not cause air and environmental pollution (Kithome et al. 1999).
Using composted manure seems more advantageous over chemical fertilizer. In addition, composted manure can be utilized not only as a final product, but also as a base material of a new product.

The compost tea is a water extract of compost, in present case of the composted manure (Riggle 1996, Islam et al. 2016). Compost tea is utilized for nutrient replenishment in crop production. During the process of compost tea preparation compost is soaking in water in order to make organic matter, beneficial microorganisms and macro- and microelements water soluble. Besides, inoculation of the compost extract with microorganisms, by which the produced composted manure can be used for plant protection purposes, is increasingly widespread (NOSB 2004, Hargreaves et al. 2008). The preparation of compost tea can be achieved under aerated conditions or nonaerated conditions (Brinton et al. 2004). It can be stated that the quality and composition of compost tea depend on the following factors: (1) composition, (2) maturity and (3) origin of the starting material (compost) and (4) the composting time (Weltzien 1992), (5) the storage and (6) extraction time (AlDahmani et al. 2003). Compost tea can be utilized as a foliar fertilizer, as well (Noble and Coventry 2005). A previous study (Yohalem et al. 1994) it was proved that compost tea can be stored for four months without loss of its effectiveness. Both in organic farming and in soil improving technologies and applications this form of fertilization is increasing (Diver. 2002).

Islam et al. (2016) tested compost teas with different parameter settings with the aim of indentification the best combination of compost tea extraction parameters for exalting both chemical and microbiological features $(\mathrm{pH}$, conductivity, total nitrogen content, total carbon and organic matter 
content, and total bacteria, fungi and actinomycetes colonies). They found that one of the most critical parameter of compost tea preparation was the designation of the compost/water ratio (or water/any other soaking material ratio). According to studies of Weltzien (1990) and Zhang et al. (1998) the ideal compost/water ratio is between $1 / 1$ and $1 / 50$, while according to Scheuerell and Manhaffee (2002) this ratio is between $1 / 3$ and $1 / 10$.

\section{MATERIALS AND METHODS}

The experiment set-ups and the laboratory tests were carried out at the University of Debrecen, Faculty of Agricultural and Food Sciences and Environmental Management, Institute of Water- and Environmental Management. The broiler poultry manure source was the deep litter husbandry units of the Baromfi-Coop Ltd. located in Nyírjákó, Hungary, where it was treated by composting. After pretreatment the composted manure was shaken on ILMVAC 05001 shaking base and sieve series with mesh sizes of $10.0 \mathrm{~mm}, 5.0 \mathrm{~mm}, 2.0 \mathrm{~mm}, 1.0 \mathrm{~mm}<1.0$ $\mathrm{mm}$, after which particles with lower size than $5.0 \mathrm{~mm}$ were used for the preparation of the compost extraction.

\section{Experiment settings}

Non-aerated compost tea was prepared in present research. During the experimental settings the following parameters were considered: compost/water ratio, extraction time, extraction temperature (Table 1).

Table 1

Applied settings of compost tea

\begin{tabular}{lc}
\hline \multicolumn{1}{c}{ Parameters } \\
\hline Compost/water ratio & $1 / 10,1 / 20,1 / 30,1 / 40,1 / 50$ \\
Extraction time & $24 \mathrm{~h}, 48 \mathrm{~h}, 72 \mathrm{~h}$ \\
Extraction temperature & $25^{\circ} \mathrm{C}$ \\
Aeration mode & non-aerated \\
\hline
\end{tabular}

In the prepared solutions, the following chemical parameters were studied: $\mathrm{pH}$, electrical conductivity (EC), nitrite, nitrate, ammonium and nitrogen content. During the measurements of the parameters, the compost tea examples were filtered a $12-15$ microns retention $0.18 \mathrm{~mm}$ thick filtered paper for 70 seconds and further work were focusing on the resulted filtered extraction.

EC (measured in $\mathrm{mS} / \mathrm{cm}$ units) and $\mathrm{pH}$ of the compost extraction were determined with HANNA HI 2550 multi-parameter benchtop meter and the measurements were performed from the undiluted filtrate.

For nutrient content measurement PF-12 Plus photometer and Visocolor ECO reagents were applied. In the case of ammonium a thousand-fold dilution was carried out for compost/water ratio values of $1 / 10$, $1 / 20,1 / 30$, and a hundred-fold dilution was used for compost/water ratio values of $1 / 40$ and $1 / 50$, while in the case of nitrite and nitrate a hundred-fold dilution was used for all compost/water ratio.

\section{RESULTS}

\section{Changes in $\mathbf{p H}$ values of compost tea}

The changes in the $\mathrm{pH}$ of compost teas are shown in Figure labc. During preparation of non-aerated compost teas the top of the bowls were sealed after which the compost extract units became incubated at $25{ }^{\circ} \mathrm{C}$.

Figure 1: pH values of compost teas under different settings

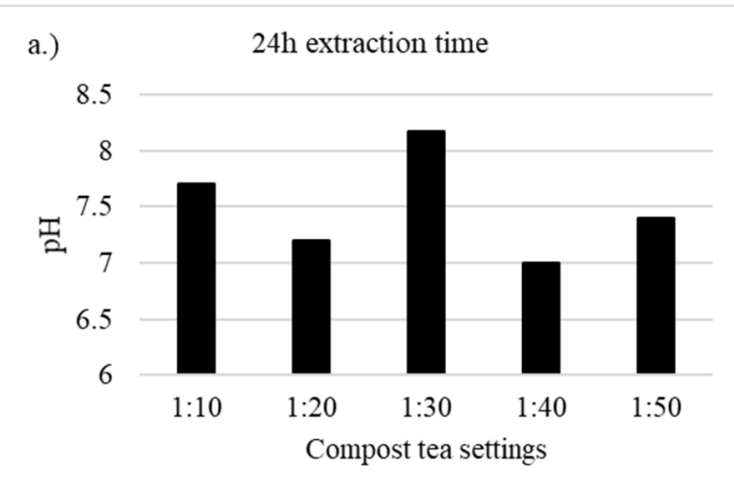

b. 48h extraction time

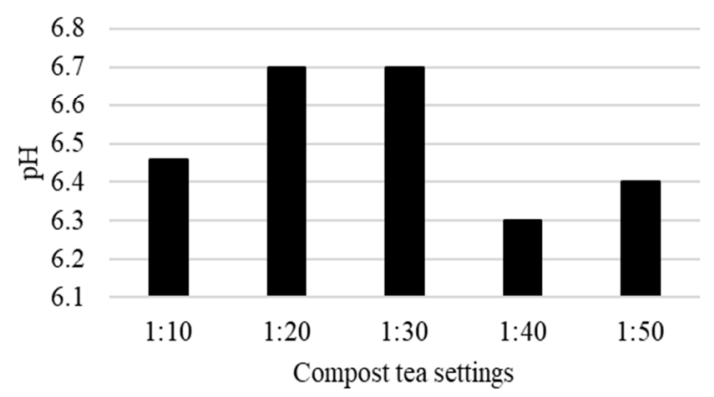

c.)

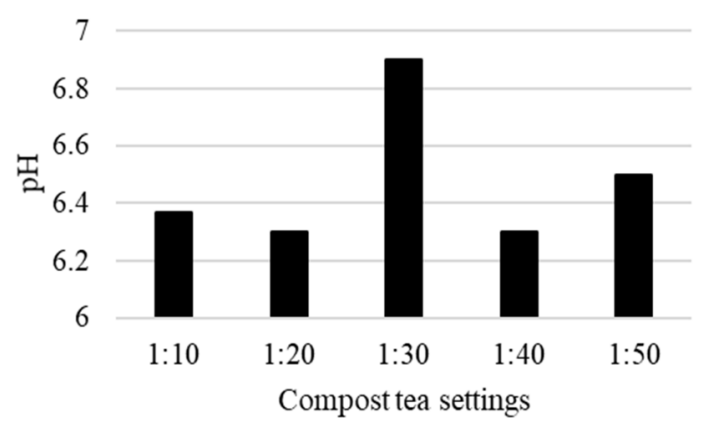

Based on the obtained results, the $\mathrm{pH}$ values of the compost teas with 24-hour long extraction time were in the neutral and slightly alkaline range $(\mathrm{pH} 7-8.1)$ (Figure la). By increasing the length of the extraction time (48-hour long, 72-hour long) the $\mathrm{pH}$ values of the solutions decreased and shifted to acidic direction, 
from 6.3 to 6.7 (Figure $1 b$ and Figure 1c). A previous study (Islam et al. 2016) has presented a similar phenomenon where the $\mathrm{pH}$ values of the compost tea decreased during incubation and storage time from 8.8 to 8.1 . The $\mathrm{pH}$ value of the non-aerated compost tea after $56 \mathrm{~h}$ of extraction was 6.08 while after 112 hours of extraction it was 5.97 (St. Martin et al. 2012).

This process can be explained by the fact that the atmospheric $\mathrm{CO}_{2}$ or $\mathrm{CO}_{2}$-produced by microbial activities (anaerobic bacteria, fungi) dissolved in compost tea forming carbonic acid, which is a weak acid, thus resulting decrease of $\mathrm{pH}$ over time (Zumdahl 1993). The pH decrease can be also explained by the anaerobic conditions which led to rot, and the acidic character increases by the shifting of $\mathrm{NH}_{4}{ }^{+} / \mathrm{NH}_{3}$ balance.

\section{Changes in the electrical conductivity of compost} tea

Figure $2 a b c$ shows the specific electrical conductivity of compost extractions.

Figure 2: Electrical conductivity values of compost teas under different settings
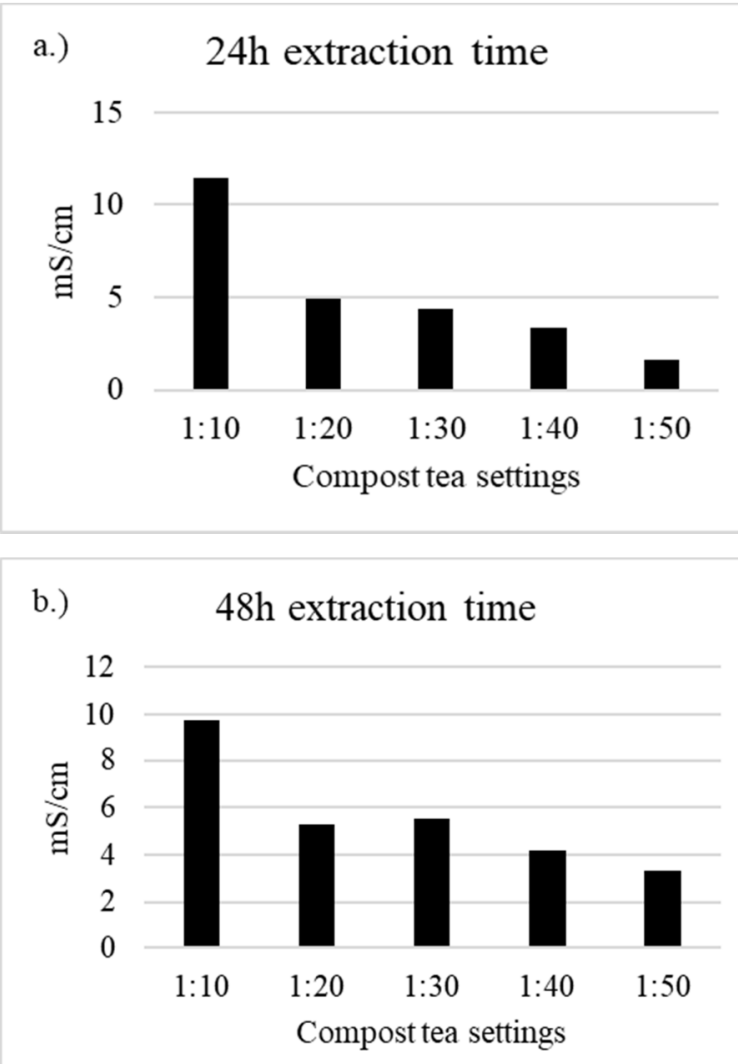

\section{c.) $\quad 72 \mathrm{~h}$ extraction time}

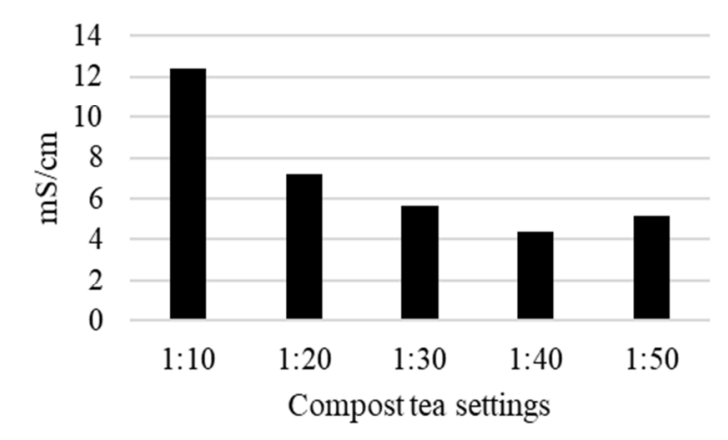

Figure 2 shows that the conductivity values of compost teas with different compost/water ratios and incubation time differ from each other. The compost tea having 1/10 compost/water ratio showed the highest electrical conductivity values $(12.39 \mathrm{mS} / \mathrm{cm})$ (Figure 2a), contrary, the electrical conductivity value of the compost tea having 1/50 compost/water ratio was much lower $(1.62 \mathrm{mS} / \mathrm{cm})$. Incubation time also influences conductivity. According to results in Figure 2 , the electrical conductivity of extractions with 24hour long incubation time, except for compost/water solution of $1 / 10$, was always lower than in the case of 72-hour long incubation time (Figure 2c). Based on the results of a previous study (St. Martin et al. 2012), the conductivity values were between $3.75 \mathrm{mS} / \mathrm{cm}$ and $4.86 \mathrm{mS} / \mathrm{cm}$.

In summary, by using larger amount of compost the extraction becomes more concentrated, thus the amount of dissolved anions and the conductivity values increase. Furthermore, the salts in the solution are present in water-soluble form, which is an available for plants.

Correlation between nitrite, nitrate and ammonium nitrogen content and the electrical conductivity

Figure 3 shows the correlation between nitrite, nitrate and ammonium nitrogen $\left(\mathrm{NO}_{2}-\mathrm{N}, \mathrm{NO}_{3}-\mathrm{N}\right.$, $\mathrm{NH}_{4}-\mathrm{N}$ ) content and specific electrical conductivity in compost extractions. The calculated strong linear correlation between nitrogen forms and conductivity $\left(\mathrm{R}^{2}=0.88\right)$ confirms that almost $90 \%$ of the salts produced in the solution are nitrogen salts. The nitrogen content $\left(\mathrm{NO}_{2}-\mathrm{N}, \mathrm{NO}_{3}-\mathrm{N}, \mathrm{NH}_{4}-\mathrm{N}\right)$ was within the range of $151-580.5 \mathrm{mg} / \mathrm{l}$, with the exception of $1 / 10$ compost/water ratio, since in the case of 24-hour, 48-hour and 72-hour long extraction the total nitrogen $\left(\mathrm{NO}_{2}-\mathrm{N}, \mathrm{NO}_{3}-\mathrm{N}, \mathrm{NH}_{4}-\mathrm{N}\right)$ content was around 1000 $\mathrm{mg} / \mathrm{l}$. 
Figure 3: Correlation of nitrogen content $\left(\mathrm{NO}_{2}-\mathrm{N}, \mathrm{NO}_{3}-\mathrm{N}, \mathrm{NH}_{4}-\mathrm{N}\right)$ and electrical conductivity

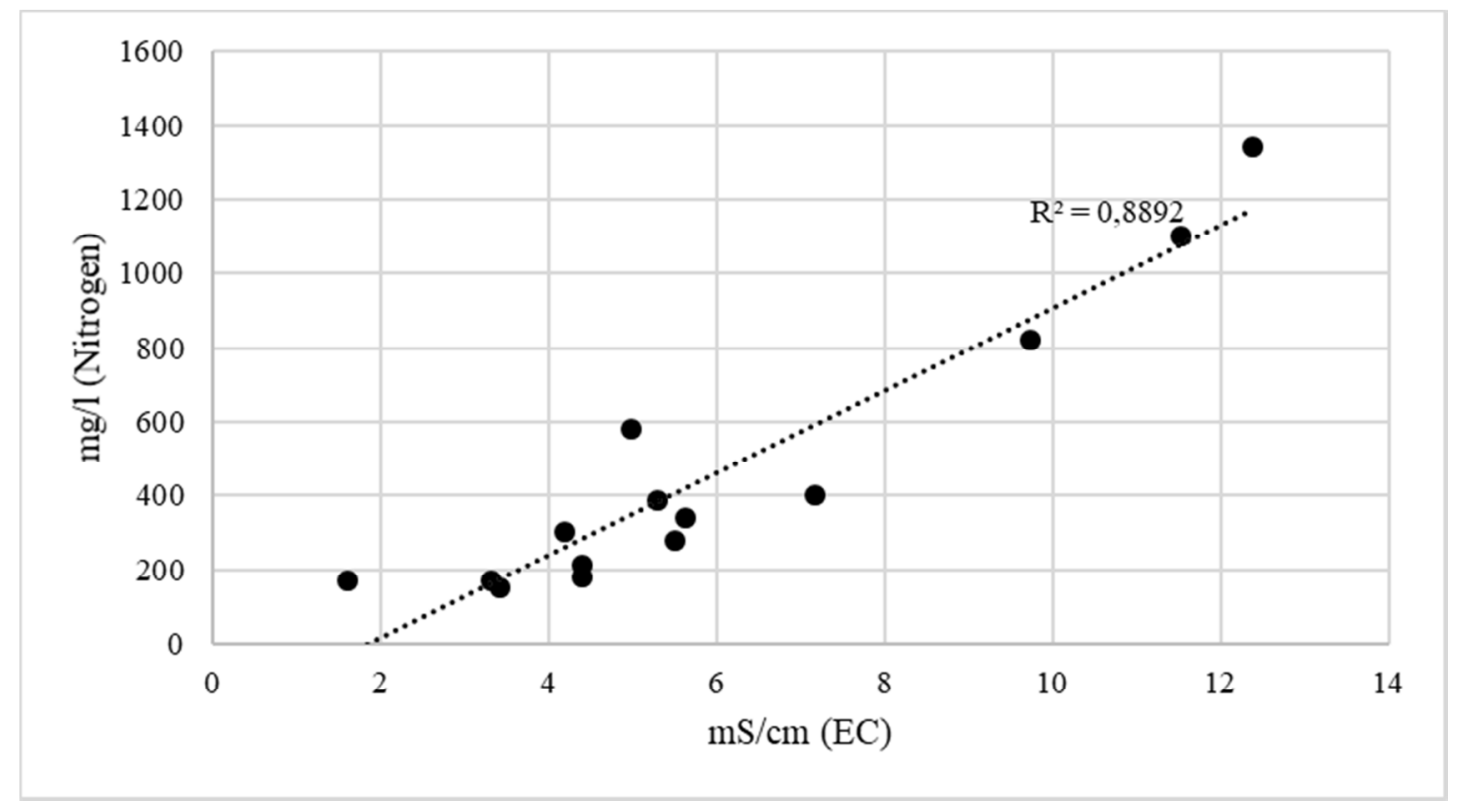

It can be stated for each compost extraction that the nitrogen content is divided between values of nitrate-nitrogen (average value in the solutions is 90.0 $\mathrm{mg} / \mathrm{l}$ ) and ammonium-nitrogen (average value in the solution is $189.1 \mathrm{mg} / \mathrm{l}$ ), while lower concentration of the reduced form, nitrite-nitrogen (average value in the solution is $0.96 \mathrm{mg} / \mathrm{l}$ ) was measured in the examined compost tea.

Presence of different nitrogen forms is significant for plant nutrition, however, the plant can absorb both nitrate and ammonium ions. However, it is important to note that the presence of nitrogen in the form of $\mathrm{NH}_{4}$ content is more favorable since ammonium in the soil is much more stable and more able to bind negatively charged soil particles than nitrate (Stefanovits et al. 1999). Nitrate binds to soil aggregates with less energy; consequently it means a higher risk of groundwater contamination.

Correlation between ammonium nitrogen and potassium content

Figure 4 shows the relationship between ammonium nitrogen and potassium content. The amount of dissolved potassium ion in the compost solutions can be explained by the high concentration of potassium in the poultry manure (500-1000 mg/l).

Figure 4: Correlation of ammonium-nitrogen and potassium content

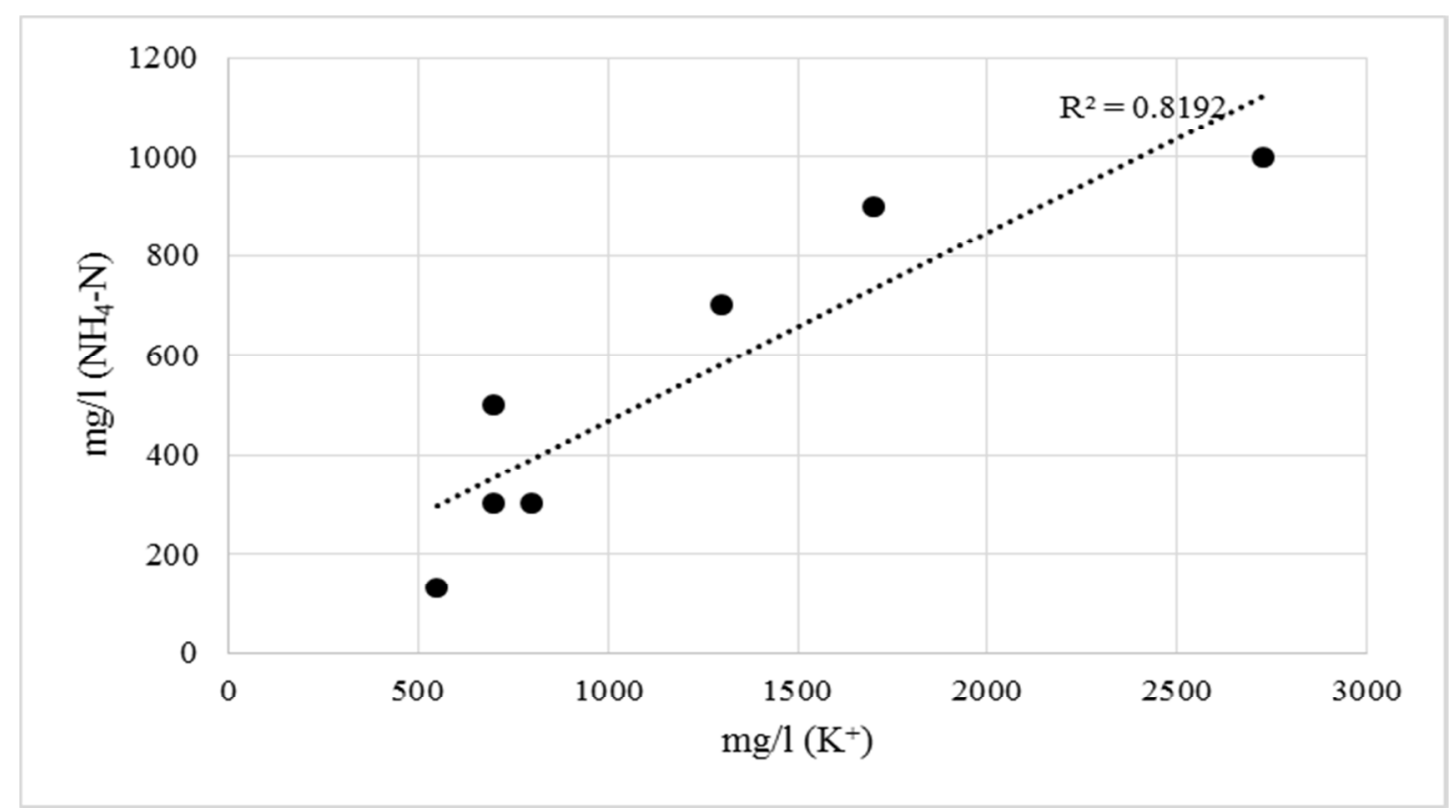


The strong linear regression with an $\mathrm{R}^{2}$ value of 0.81 between potassium and ammonium nitrogen is explained by the fact that in non-aerated solutions rotting processes started due to the anaerobic conditions. In the case of ammonification resulted by anaerobic conditions the potassium concentration will be detected in larger amount in the solution due to the acidic $\mathrm{pH}$.

The compost tea which produced by manure is called manure tea. The manure tea contains soluble nutrients which are soluble from the manure and the solution has a high nitrate, salt, phosphorus and potassium content (Ingham 2005). In this case the solutions I make can also be called manure tea.

\section{DISCUSSION}

Examining the laboratory parameters of nonaerated compost tea, it can be stated that the concentration of nutrients in solution significantly determines the $\mathrm{pH}$ of the solution. The oxygen-poor and anaerobic conditions helped ammonification, which resulted in higher concentration of potassium ions released due to acidic $\mathrm{pH}$. Electrical conductivity is largely determined by the quantity of nitrogen forms in solution, especially ammonium and nitrate-nitrogen. From the aspect of nutrient supply, the compost tea preparation requires further laboratory testing. In addition, the production of aerated compost tea and the comparison of their constituents with non-air compost solutions essentially determine the main direction of further research.

\section{ACKNOWLEDGEMENTS}

Hereby I would like to thank my supervisor, Prof. Dr. János Tamás and the Institute of Water and Environment Management for their help in my research. I would like to thank the Baromfi-Coop Ltd. for providing the base material for our experiments.

The publication is supported by the EFOP-3.6.3VEKOP-16-2017-00008 project. The project is cofinanced by the European Union and the European Social Fund.

\section{REFERENCES}

Al-Dahmani, J. H--Abbasi, P. A--Miller, S. A--Hoitink, H. A. J. (2003): Suppression of bacterial spot of tomato with foliar sprays of compost extracts under greenhouse and field conditions. Plant Disease. 87: 913-919.

Brinton, W.-Storms, P.-Evans, E.-Hills, J. (2004): Compost teas: Microbial hygiene and quality in relation to method of preparation. Woods End Research Laboratory reprint from Journal of Biocycle.

Casado, G. I. G.-de Molina, M. G. (2009): Preindustrial agriculture versus organic agriculture: the land cost of sustainability. Land Use Policy. 26: 502-510.

Csaba L.-Kiss O.-Vermes L.-Szinay M. (1978): Hígtrágyahasznosítás. Mezőgazdasági Kiadó. Budapest. 290.

Diver, S. (2002): Notes on Compost Teas: A Supplement to the ATTRA Publication: Compost Teas for Plant Disease Control. Appropriate Technology Transfer for Rural Areas (ATTRA) http://www.attra.ncat.org

Gaál K. (2011): Trágyakezelés és -hasznosítás a baromfitelepeken. [In: Bogenfürst F. et al. Baromfitenyésztés.] Kaposvári Egyetem-Pannon Egyetem-Nyugat-Magyarországi Egyetem. 399

Hargreaves, J. C.-Adla, M. S.-Warman, P. R. (2008): Are compost teas an effective nutrient amendment in the cultivation of strawberries? Soil and plant tissue effects. Journal of the Science of Food and Agriculture. 89: 390-397.

Islam, M. K.-Yaseen, T.-Traversa, A.-Kheder, M. B.-Brunetti, G.Cocozza, C. (2016): Effects of the main extraction parameters on chemical and microbial characteristics of compost tea. Waste Management. 52: 62-68.

Ingham, R. E. (2005): The compost tea brewing manual US Printings. Soil Foodweb Incorporated. Oregon. 91.

Kithome, M.-Paul, J. W.-Bomke, A. A. (1999): Reducing nitrogen losses during simulated composting of poultry manure using adsorbents or chemical amendments. Journal of Environmental Quality. 28: 194-201.
Kovács G. (2011): Az elhullott állatok és a melléktermékek kezelése. [In: Bogenfürst F. et al. Baromfitenyésztés.] Kaposvári Egyetem-Pannon Egyetem-Nyugat-Magyarországi Egyetem. 399.

Matson, P. A.-Patron, W. J.-Power, A. G.-Swift, M. J. (1997): Agricultural intensification and ecosystem properties. Science. 277: 504-509.

National Organic Standards Board, Compost Tea Task Force Report. NOSB (2004): http://www.ams.usda.gov/nosb/meetings/ CompostTeaTaskForceFinalReport.pdf

Noble, R.-Coventry, E. (2005): Suppression of soil-borne plant diseases with composts: a review. Biocontrol Science and Technology. 15: 3-20.

Ogunwande, G. A.-Osunade, J. A.-Adekalu, K. O.-Ogunjimi, L. A. O. (2008): Nitrogen loss in chicken litter compost as affected by carbon to nitrogen ratio and turning frequency. Bioresource Technology. 99: 7495-7503.

Riggle, D. (1996): Compost teas in agriculture. BioCycle. 37: 65-67. Scheuerell, S.-Mahaffee, W. (2002): Compost tea: Principles and prospects for plant disease control. Compost Science and Utilization. 10. 4: 313-338.

Stefanovits P.-Filep Gy.-Füleky Gy. (1999): Talajtan. Mezőgazda Kiadó. Budapest. 433.

St. Martin, C. C. G.-Dorinwil, W.-Brathwaite, R. A.-Ramsubhag, A. (2012): Effects and relationships of compost type, aeration and brewing time on compost tea properties, efficacy against Pythium ultimum, phytotoxicity and potential as a nutrient amendment for seedling production. Biological Agriculture \& Horticulture. 28. 3: 185-205.

Vandermeer, J. (1995): The ecological basis of alternative agriculture. Annual Review of Ecology. Evolution and Sytematics. 26: 201-224.

Weltzien, H. C. (1990): The Use of Composted Materials for Leaf Disease Suppression in Field Crops. Monograph-British Crop Protection Council. 115-120. 
Yohalem, D.-Harris, R.-Andrews, J. (1994): Aqueous extracts of spent mushroom substrate for foliar disease control. Compost Science and Utilization. 2: 67-74.
Zhang, W.-Han, D.-Dick, W.-Davis, K.-Hoitink, H. (1998): Compost and compost water extract-induced systemic acquired resistance in cucumber and Arabidopsis. Phytopathology. 88: 450-455.

Zumdahl, S. S. (1993): Chemistry. $3^{\text {th }}$ edition. D.C. Heath \& Co. 654. 